\title{
MORPHOMETRIC ANALYSIS OF THE FORAMEN MAGNUM OF DRY HUM AN SKULLS IN NORTH INDIAN POPULATION
}

\section{Rajkumar *1, Prabhakaran kattimuthu ${ }^{2}$, Punita Manik ${ }^{3}$ Vikram Singh 4.}

${ }^{* 1}$ Ph.D Scholar, Geetanjali M edical College\& Hospital, Udaipur, Rajasthan, India.

2 Professor, Anatomy department, Geetanjali Medical College\& Hospital, Udaipur, Rajasthan, India.

3 Professor, Anatomy department, KGM U, Lucknow, U.P, India.

${ }^{4}$ Associate Professors, ECE-Department, Glocal University, Saharanpur, U.P, India.

\section{ABSTRACT}

Background: Morphometric analysis of the foramen magnum of dry human skulls in North Indian population was carried out to demonstrate the anatomical variations in morphology. The dimensions of the foramen magnum are clinically important because vital structures passing through it may endure compression in diseases associated with foramen magnum like herniation, meningiomas and achondroplasia.

Objectives: The knowledge of various dimensions of the foramen magnum and foramen magnum diameters are needed to determine some malformations like Arnold Chiari syndrome in which the transverse diameter is increased.

Materials and Methods: 298 dry skulls of adult human being were studied. Anteroposterior and Transverse Diameter were measured by using a Digital Vernier caliper. The cranial base was visually assessed for the shape of foramen magnum. Additionlly, the area and index of foramen magnum were also calculated.

Results: The mean anteroposterior and transverse diameter of the foramen magnum were $34.13 \pm 2.44 \mathrm{~mm}$ and $28.32 \pm 2.042 \mathrm{~mm}$. The mean area and index of the foramen magnum were $754.32 \pm 105.6 \mathrm{~mm}$ and $83.14 \pm 6.33 \mathrm{~mm}$ respectively

Conclusion: The anteroposterier diameter of foramen magnum was more than the transverse diameter and around $66 \%$ seen in foramen magnum are oval shaped.

KEY WORDS: M orphometry, Antero-Posterior Diameter, Transverse Diameter, Foramen M agnum.

Address for Correspondence: Dr. Rajkumar, Ph.D Scholar, Geetanjali M edical College\& Hospital, Udaipur, Rajasthan, India. E-Mail: dr.rajkumarghanghas@yahoo.com

\begin{tabular}{|l|l|}
\hline \multicolumn{3}{|c|}{ Access this Article online } \\
\hline Quick Response code & Web site: International Journal of Anatomy and Research \\
ISSN 2321-4287 \\
www.ijmhr.org/ijar.htm \\
\cline { 2 - 3 }
\end{tabular}

\section{INTRODUCTION}

The foramen magnum lies in an antero-median position. It is oval, wider behind, with its greatest diameter being anteroposterior. It contains the lower end of the medulla oblongata, the vertebral arteries and the spinal accessory nerve. Anteriorly, the margin of the foramen magnum is slightly overlapped by the occipital condyles which project down to articulate with the superior articular facets on the lateral masses of the atlas [1].

The foramen magnum occupies the central area of the floor and transmits the medulla oblongata and its surrounding meninges, the 
ascending spinal parts of the accessory nerves, and the two vertebral arteries [2].

Therefore, the evaluation of morphometric of foramen magnum is helpful for forensic dentistry and medicine.These study can be used as part of an investigative process prior to more sophisticated and expensive analyses such as the DNA examination [3].

It is attributed that the developmental and acquired craniocervical junction disorder, achondroplasia are commonly observed. Achondroplasia, the most common form of dwarfism, causing in abnormal in enchondral bone formation at the cranial base which leads to narrow cervical spinal canal and stenotic foramen magnum.

Clinical manifestations of chronic brainstem compression by stenosis of the foramen magnum and related to structures are respiratory complications, lower cranial nerve dysfunctions, upper and lower extremity paresis, hypo- or hypertonia, hyperreflexia or clonus, and general motor development delay [4].

Recent studies report that foramen magnum in patients with Chiari1 ${ }^{\text {st }}$ and Chiari $2^{\text {nd }}$ malformations has been found to be different than in the normal population. The development of symptoms has been found in patients with shorter anteroposterier diameter of the foramen magnum. Further-more, diseases associated with stenosis of the craniovertebral junction involve craniometaphyseal dysplasia, Jeune's asphyxiating thoracic dystrophy, spherophakiabrachymorphism (M archesanis syndrome). Stenosis of the foramen magnum has also been reported for Bear-Stevenson syndrome, a craniofacial syndrome characterized by hypertrophy of bony margins. The wider foramen magnum has also been appreciated in patients with diastrophic dysplasia. The conclusion for the diagnosis and treatment plan of such disorders include various bony abnormalities finding in changes of the anatomy of the foramen magnum demands a good understanding of normal anatomy of this structure [4].

There are numerous openings in the base of the skull they are called foramina. Foramen magnum is the largest opening at the base of skull present in the posterior cranial fossa at lower part of the occipital bone and is the outlet through which the medulla and spinal cord pass from the skull to the vertebral column [5]. Few reports on variations in shape of foramen magnum are available. Different shapes noted are oval, egg shaped, round, tetragonal, pentagonal, hexagonal and irregular, commonest being oval. The importance of variations in shape is due to its effects on the vital structures passing through it.

The fundamental knowledge of foramen magnum as well as craniometeric measurements of craniovertebral region are very important in order to know the pathophysiology of this region. The dimensions of the foramen magnum are clinically important because the above mentioned various structures passing through it may endure compression such as in cases of foramen magnum herniation, foramen magnum meningiomas and foramen magnum achondroplasia ${ }^{6}$. The knowledge of foramen magnum diameters is needed to determine some malformations such as Arnold Chiari syndrome, which shows expansion of transverse diameter [7].

\section{MATERIALS AND METHODS}

The total number of 298 dry adult human crania of unknown sex were analyzed from the Department of Anatomy, GSVM Medical College, Kanpur and KGMU, Lucknow (U.P).

M orphometric measurement - anterioposterior diameter (APD) \& transverse diameter (TD)) of the foramen magnum was measured using digital Vernier Caliper to an accuracy of $0.5 \mathrm{~mm}$. APD of the foramen magnum is the distance between opisthion to basion along the midsagittal plane as shown in figure-1(a). TD is the maximum distance along the transverse plane. The opisthion is the midpoint on the posterior margin of the foramen magnum. The basion located at the midpoint on the anterior margin of the foramen magnum as shown in figure-1(b). The area of the foramen was calculated from length and width of foramen magnum utilizing formulae given by Radnsky fourmlae 1/4 LFM $\times$ WFM $\times 3.14$, where LFM \&WFM are length \& width of foramen magnum respectively [8].

Index of foramen magnum were calculated by using the formula, transverse diameter $X 100 /$ antero-posterior diameter ${ }^{9}$.The statistical analy- 
sis used for the study is SPSS (Statistical Package for Social Sciences, IBM ).Version 21.

\section{OBSERVATIONS}

The various measurements of foramen magnum were made in 298 skulls which are recorded and tabulated in Table 1.The mean anteroposterior diameter of foramen magnum was33.98 \pm 2.75 $\mathrm{mm}$, ranging from $21.12 \mathrm{~mm}$ to $42.02 \mathrm{~mm}$. The mean transverse diameter of foramen magnum was $28.16 \pm 2.15 \mathrm{~mm}$, ranging from $22.61 \mathrm{~mm}$ to $33.57 \mathrm{~mm}$. The mean area and index of the foramen magnum were $754.32 \pm 105.6 \mathrm{~mm}$ and $83.14 \pm 6.33 \mathrm{~mm}$.

The shape of the foramen magnum were noted and are given below in the decreasing frequency:-oval $66 \%$, rounded $24.83 \%$, hexagonal $4.02 \%$, tetragonal $3.35 \%$, pentagonal $2.68 \%$, shapes (Table 2).

Table 1: M ean $\pm S D$ of Foramen M agnum.

\begin{tabular}{|c|c|c|c|c|}
\hline $\begin{array}{c}\text { Sample } \\
\text { size }\end{array}$ & $\begin{array}{c}\text { Anteroposterior } \\
\text { Diameter } \\
\text { Mean } \pm S D\end{array}$ & $\begin{array}{c}\text { Transverse Diameter } \\
\text { Mean } \pm S D\end{array}$ & $\begin{array}{c}\text { Area } \\
\text { Mean } \pm S D\end{array}$ & $\begin{array}{c}\text { Index } \\
\text { Mean } \pm S D\end{array}$ \\
\hline 298 & $33.98 \pm 2.75$ & $28.16 \pm 2.15$ & $754.32 \pm 105.16$ & $83.14 \pm 0.33$ \\
\hline
\end{tabular}

Table 2: Showing of shape of foramen magnum.

\begin{tabular}{|c|c|}
\hline Population & Indian \\
\hline Sample & 298 \\
\hline Round & 24.83 \\
\hline Oval & 66 \\
\hline Tetragonal & 3.35 \\
\hline Hexagonal & 4.02 \\
\hline Pentagonal & 2.68 \\
\hline
\end{tabular}

Fig. 1: (a) Anterioposterior diameter and

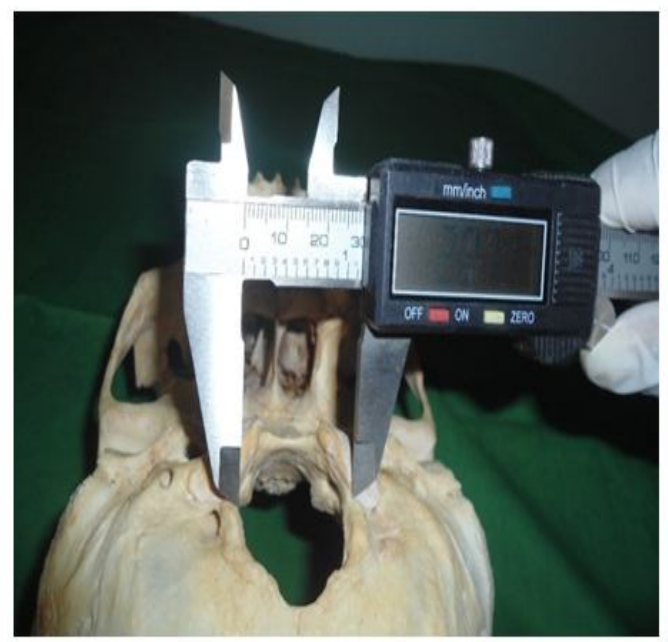

\section{DISCUSSION}

In the present study, the average anteroposterior diameter of foramen magnum was $33.98 \pm 2.75 \mathrm{~mm}$ within range from $21.12 \mathrm{~mm}$ to $42.02 \mathrm{~mm}$. The comparison of anteroposterior and transverse diameter of the present study with the study done by other authors are shown in table 3. These findings are similar to the findings of Osunwok EA, Muthukumar, Sanjukta Sahoo, Shikha Sharma, Govsa, and Kizikanat, Avci,Chethan,Wanebo \& Chinoine,Berge Bergmann shown in Table 3.

The mean area of foramen magnum was $754.32+105.16 \mathrm{~mm}$, within range from $22.61 \mathrm{~mm}$ in this study which is comparable within the values reported by Shikha Sharma,Govsa, and Wanebo \& Chinoine, as shown in table no.3 These authors have worked on the morphometric analysis of Foramen magnum from different parts of the globe. The data obtained from the present study was compared with the data reported by other authors. After the comparison, we observed that our findings are almost similar.

The anteroposterier diameter of foramen magnum was more than the transverse diameter and around $66 \%$ seen in foramen magnum are oval shaped. The difference in shapes of the foramen magnum from various reports accordance other racial variability among the morphology. According to Shikha Sharma, Murshed, Anil Sharma in showing Table.No.4. The mean index of the foramen magnum was $83.14 \pm 6.33 \mathrm{~mm}$ (Table 4).

(b) transverse diameter of formen magnum.

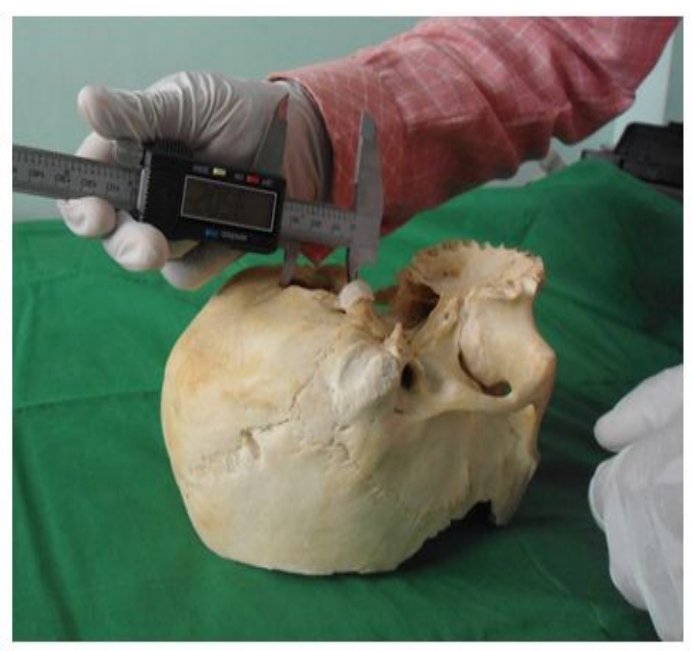


Table 3: Showing comparison of anteroposterior and transverse diameters of foramen magnum.

\begin{tabular}{|c|c|c|c|c|c|c|c|c|}
\hline Author & Population & Specimens & SEX & $\begin{array}{l}\text { Sample } \\
\text { size }\end{array}$ & $\begin{array}{l}\text { Anteroposterior } \\
\text { Diameter }\end{array}$ & $\begin{array}{c}\text { Transverse } \\
\text { Diameter }\end{array}$ & Area & Index \\
\hline Present & Indian & DS & $\mathrm{n} / \mathrm{a}$ & 411 & $33.98 \pm 2.75$ & $28.16 \pm 2.12$ & $754.32 \pm 105.16$ & $83.14 \pm 6.33$ \\
\hline Osunwoke EA [10] & Nigeria & DS & $\mathrm{n} / \mathrm{a}$ & 120 & $36.11+2.6$ & $29.56 \pm 2.6$ & N.A & N.A \\
\hline Muthukumar N [11] & Indian & DS & $\mathrm{n} / \mathrm{a}$ & 50 & 33.3 & 27.9 & N.A & N.A \\
\hline Sanjukta Sahoo [12] & Indian & $\overline{D S}$ & $\mathrm{n} / \mathrm{a}$ & 150 & $35.30 \pm 2.709$ & $29.49 \pm 2.57$ & N.A & N.A \\
\hline Shikha Sharma [13] & Indian & DS & $\mathrm{n} / \mathrm{a}$ & 50 & 38.76 & 33.44 & 970.57 & N.A \\
\hline Govsa et al [14] & Turkey & $\overline{D S}$ & $n / a$ & 144 & $37.2 \pm 3.5$ & $30.8 \pm 2.9$ & $829 \pm 137.7$ & N.A \\
\hline Kizikanat et al [15] & Turkey & DS & $\mathrm{n} / \mathrm{a}$ & 59 & $34.8 \pm 2.2$ & $29.6 \pm 2.4$ & $\mathrm{n} / \mathrm{a}$ & N.A \\
\hline Avci et al [16] & Turkey & DS & $\mathrm{n} / \mathrm{a}$ & 30 & 34.5 & 29 & $\mathrm{n} / \mathrm{a}$ & N.A \\
\hline Chethan et al [17] & Indian & DS & $\mathrm{n} / \mathrm{a}$ & 53 & $31+2.4$ & $25 \pm 2.4$ & $\mathrm{n} / \mathrm{a}$ & N.A \\
\hline Wanebo \&Chinoine [18] & USA & DS & $n / a$ & 32 & $36 \pm 3$ & $31 \pm 2$ & $780 \pm 110$ & N.A \\
\hline Berge \& Bergmann [19] & USA & DS & $\mathrm{n} / \mathrm{a}$ & 100 & 33.8 & 28.3 & $\mathrm{n} / \mathrm{a}$ & N.A \\
\hline
\end{tabular}

Table 4: Showing comparison of percentage of different shapes of foramen magnum.

\begin{tabular}{|c|c|c|c|c|}
\hline Shape & Present study & $\begin{array}{c}\text { Shikha Sharma } \\
\text { et al. [13] }\end{array}$ & $\begin{array}{c}\text { Murshed } \\
\text { et al. [6] }\end{array}$ & $\begin{array}{c}\text { Anil Kumar et al. } \\
\text { [20] }\end{array}$ \\
\hline Population & Indian & Indian & & USA \\
\hline Speciemen & DS & DS & DS & DS \\
\hline Sample & 298 & 50 & 88 & 36 \\
\hline Round & 24.83 & 22 & 21.8 & 20 \\
\hline Oval & 66 & 16 & 8.1 & 50 \\
\hline Irregular & ---- & 18 & 19.9 & 16 \\
\hline Tetragonal & 3.35 & 12 & 12.7 & 6 \\
\hline Hexagonal & 4.02 & 8 & 17.2 & 8 \\
\hline Pentagonal & 2.68 & 8 & ----- & N.A \\
\hline
\end{tabular}

\section{CONCLUSION}

The present study on the morphometric analysis of 298 skulls showed that the anteroposterier diameter of foramen magnum of skull were more than the transverse diameter and the shape found in the foramen magnum are oval shaped in $66 \%$ human skulls of north Indian region.

These findings may be helpful for anatomists and neurosurgeons to approach the cranial base with maximum safety and minimum mortality and morbidity or clinicians in reaching the appropriate diagnosis.

\section{Conflicts of Interests: None}

\section{REFERENCES}

[1]. Willams PL, Bannister LH, Martin M M Collins, P., Dyson, M. and Dussek, JE.MWJ, Gray's Anatomy $\left(40^{\text {th }}\right.$.) Churchill Livigstone, London, pp415.

[2]. Richard S. Snell,"Clinical Neuroanatomy" ed. $7^{\text {th }}$ .p.195.

[3]. Manoel C, Prado FB, Caria PHF, Groppo FC. M orphometric analysis of the foramen magnum in human skulls of brazilian individuals: its relation to gender. Braz. J. Morphol. Sci 2009; 26(2): 104-108.
[4]. Tubbs RS, Griessenauer CJ, Loukas M, Shoja M M, Cohen-Gadol AA. M orphometric analysis of the foramen magnum: an anatomic study. Neurosurgery 2010;66:385-8.

[5]. M c Graw Hill Concise Dictionary of M odern Medicine (2002): M c Graw Hill Companies Inc.

[6]. Murshed KA, Çiçekçibasi AE, Tuncer I. M orphometric Evaluation of the Foramen M agnum and Variations in its Shape: A Study on Computerized Tomographic Images of Normal Adults.Turkish Journal of Medical Sciences. 2003;33(1):301-306.

[7]. Sgouros S, Goldin HJ, Hockely AD, Wake MJ, et al. Intracranial volume change in childhood. J Neurosurge.1999;610-616.

[8]. Radinsky L. Relative brain size a new measure. Science 1967;155:836-838.

[9]. M artin R. Saller K. Lehrbuch de Anthropologie. Band 1.Stuttgart: Gustov Fisher Verlag, 1957;455-509.

[10]. Osunwoke EA, Oladipo GS, Gwunireame IU, Ngaokere J0,2012; Morphometric analysis of the foramen magnum and jugular foramen in adult skull in southern Nigerian population. Am J Sci Ind Res 2012;3:446-8.

[11]. M uthukumar N, Swaminathan R, Venkatesh G, Bhanumathy SP. A morphometric analysis of the foramen magnum region as it relates to the transcondylar approach. Acta Neurochir (Wien). 2005;147(8):889-95.

[12]. Sanjukta Sahoo,Sanjay Kumar Giri et al morphometric Analysis of the foramen magnum and occipital condyles. Int.J.Pharma.Sci.Rev.Res., 2015; 33(2):198-204. 
[13].Shikha Sharma, Anil Kumar Sharma , Bhawani Shankar Modi, Mohd. Arshad. MORPHOMETRIC EVALUATION OF THEFORAM EN M AGNUM ANDVARIATION IN ITS SHAPE AND SIZE: A STUDY ON HUM AN DRIED SKULL. International Journal of Anatomy and Research, Int J Anat Res 2015;3(3):1399-03. ISSN 2321- 4287.

[14]. Govsa F, Ozer MA, Celik S, Ozmutaf NM. Three-dimensional anatomic landmarks of the foramen magnum for the craniovertebral junction. J Craniofac Surg 2011; 22:1073-6.

[15]. Kizilkanat ED, Boyan N, Soames R, Oguz. M rphometry of the hypoglossal canal, occipital codyle and foramen mgnum. Neurosurg Quarter James Cook Univ 2006;16:121-5.

[16]. Avci E, Dagtekin A, Ozturk AH, Kara E, Ozturk NC, Uluc K, et al. Anatomical variations of the foramen magnum, occipital condyle and jugular tubercle. Turk Neurosurg 2011;21:181-90.
[17]. Chethan P, Prakash KG, Murlimanju BV, Prashanth KU,Prabhu LV, Saralaya W. et al. Morphological analysis and morphometry of the foramen magnum: an anatomical investigation. Turk Neurosurg 2012;22:416-9.

[18]. Wanebo JE, Chicoine MR. Quantitative analysis of the transcondylar approach to the foramen magnum.Neurosurgery 2001;49:934-41. (discussion 941-3).

[19]. Berge JK, Bergman RA. Variations in size and in symmetry of foramina of the human skull. Clin Anat 2001;14:406.

[20]. Anil Kumar, M itesh Dave, Sanam Anwar. Morphometric Evalvation of Foramen Magnum in Dry Human Skulls. Int J Anat Res 2015;3(2):1015-23.

\section{How to cite this article:}

Rajkumar, Prabhakaran kattimuthu, Punita M anik Vikram Singh. M ORPHOM ETRIC ANALYSISOF THEFORAM EN M AGNUM OFDRY HUM AN SKULLS IN NORTH INDIAN POPULATION. Int J Anat Res 2017;5(1):3480-3484. DOI: 10.16965/ijar.2016.495 